Vidya Samhita : Jurnal Pelelitian Agama

Volume 7, Nomor 1, 2021. pp $76-85$

p-issn : 2460 - 3376, e-issn : $2460-4445$

https://www.ejournal.ihdn.ac.id/index.php/vs/indexa

\title{
PRO KONTRA SUNAT PEREMPUAN DI INDONESIA: SEBUAH ANALISIS WACANA
}

Putu Dian Prima Kusuma Dewi ${ }^{1}$, Putu Sukma Megaputri ${ }^{1}$ I Wayan Sujana ${ }^{2}$

\author{
dianpreema@gmail.com \\ ${ }^{1}$ Prodi S-1 Kebidanan Sekolah Tinggi Ilmu Kesehatan Buleleng \\ 2 Prodi S1 Keperawatan Sekolah Tinggi Ilmu Kesehatan Buleleng
}

\begin{abstract}
Circumcision of women in Indonesia is carried out generally based on the existence of community traditions that are passed down through generations. This literature review is done by collecting several scientific articles related to female circumcision. This literature aims to add insight and study related to the pros and cons of female circumcision in Indonesia. Female circumcision itself in Indonesia is regulated in Permenkes number 1636 / Menkes / Per / XI / 2010 which initially aimed to ensure the safety and protection of the female reproductive system because in fact there are still many practices of female circumcision carried out by dukuns and in secret. However, this indicates precisely to legalize circumcision for women who clearly have no evaluation that shows that circumcision is beneficial to women's reproductive health. Various reactions emerged in the community so that the Permenkes on female circumcision was revoked in 2013. So female circumcision was a tradition that shifted towards medicalization which was beneficial for men but detrimental to women. Medically female circumcision has not shown the level of validity of goodness that can be accounted for. The tradition of female circumcision is most likely based on the myths that develop in society, which considers women to be subordinated creatures from men.
\end{abstract}

Keywords: Circumcision, Pro Cons, Women

\begin{abstract}
Abstrak
Sunat kaum perempuan di Indonesia dilakukan umumnya didasari oleh adanya tradisi masyarakat yang diwariskan secara turun-temurun. Literature review ini dilakukan dengan mengumpulkan beberapa artikel ilmiah terkait sunat perempuan. Literature ini bertujuan untuk menambah wawasan dan kajian terkait pro dan kontra sunat perempuan di Indonesia. Sunat perempuan sendiri di Indonesia diatur dalam Permenkes nomor 1636/Menkes/Per/XI/2010 yang awalnya bertujuan untuk menjamin keamanan dan
\end{abstract}


perlindungan sistem reproduksi perempuan karena faktanya di Indonesia masih banyak praktek sunat perempuan dilakukan oleh dukun bayi dan secara rahasia. Namun hal ini justru mengindikasikan untuk melegalkan tindakan sirkumsisi pada perempuan yang jelasjelas belum ada evaluasi yang menunjukkan bahwa sirkumsisi itu bermnafaat bagi kesehatan reproduksi perempuan. Berbagai reaksi muncul di masyarakat sehingga Permenkes tentang sunat perempuan ini dicabut pada tahun 2013. Jadi sunat perempuan itu merupakan sebuah tradisi yang bergeser kearah tindakan medikalisasi yang bermanfaat bagi kaum laki-laki namun merugikan bagi kaum perempuan. Secara medis khitan perempuan belum menunjukkan tingkat validitas kebaikan yang dapat dipertanggungjawabkan. Tradisi khitan perempuan berkemungkinan besar didasarkan atas mitos-mitos yang berkembang di masyarakat, yang menganggap perempuan sebagai makhluk subordinasi dari laki-laki.

Kata Kunci: Sunat, Pro Kontra, Perempuan

\section{Pendahuluan}

Pembangunan kesehatan harus dilihat sebagai investasi peningkatan kualitas sumber daya manusia suatu negara yang antara lain diukur dengan Indeks Pembangunan Manusia (IPM) dimana kesehatan adalah salah satu komponen utama selain pendidikan dan pendapatan. Perhatian khusus diberikan kepada pelayanan kesehatan bagi penduduk miskin, daerah tertinggal dan daerah bencana dengan memperhatikan kesetaraan gender. Selanjutnya melihat perkembangan sejak bangsa Indonesia merdeka hingga sekarang menunjukkan permasalahan kesehatan belum berkeadilan gender. Hal ini terlihat dari berbagai indicator, dimana masalah kesehatan perempuan (kesehatan reproduksi) masih menimpa perempuan Indonesia. misalnya sunat perempuan, tingkat kematian ibu yang masih tinggi, tingginya aborsi, tingkat infeksi menular seksual termasuk HIV/AIDS juga relative tinggi, angka peserta KB aktif yang tidak meningkat, rendahnya partisipasi pria dalam keluarga berencana, serta kurangnya pengetahuan keluarga, tentang kesehatan reproduksi. Selain itu juga permasalahan kompetensi penolong persalinan masih kurang, masih banyak pertolongan persalinan oleh dukun, meningkatkan kasus kekerasan, kuatnya budaya patriarkhi dan menopause. Artinya permasalahan kesehatan yang menimpa perempuan lebih banyak terkait dengan fungsi reproduksinya (Siahaan,2010).

Indonesia sebagai Negara yang menghargai budaya dan tradisi banyak pula mewariskan budaya terkait kesehatan perempuan bila dikaji ada yang menguntungkan dan merugikan. Masalah kesehatan reproduksi pada perempuan yang sangat dekat dengan masalah gender bahkan selalu menjadi topik yang menimbulkan pro kontra di Indonesia maupun dunia global seperti khitan atau sunat alat kelamin perempuan. Berbagai tujuan dan alasan seperti tradisi, agama juga alasan kebersihan dan mencegah perempuan mengumbar nafsu seksual sebagai dasar pelaksanaan sunat perempuan bagi masyarakat Indonesia di beberapa wilayah seperti Yogyakarta, Madura, Jawa Barat, Sumatra, Sulawesi dan Kalimanatan Selatan. Praktik khitan perempuan ini sebenarnya tidak hanya terjadi di Indonesia tetapi juga di beberapa Negara lain di wilayah Afrika, Asia, Timur Tengah, Semenanjung Arab, Australia dan Amerika Latin (Putranti, 2003). 
Sunat kaum perempuan di Indonesia dilakukan umumnya didasari oleh adanya tradisi masyarakat yang diwariskan secara turun-temurun. Tradisi yang dimaksud adalah sesuatu yang berada di luar kemauan individu, di luar kemampuan perseorangan, dan memaksakan kehendaknya pada setiap individu. Adanya tekanan-tekanan sosial sering menghalangi individu untuk melakukan hal-hal yang sebetulnya

diinginkan (Oktarina, 2011). Khitan atau sunat merupakan suatu tradisi, yaitu dengan cara memotong kulup (kulit luar kelamin laki-laki) yang bertujuan agar penis menjadi bersih dan kotoran yang keluar dari saluran kemih tidak terhambat. Perempuan tidak memiliki kulup, sehingga sunat perempuan tidak sebenarnya tidak perlu dilakukan (Suryansyah, 2011).

Penelitian di Somalia Afrika, menyebutkan sunat perempuan merupakan masalah kesehatan masyarakat yang utama yang sebagian besar memberikan kontribusi untuk kesakitan dan kesehatan perempuan serta anak-anak mereka secara global. Dengan demikian, masyarakat internasional berkomitmen untuk mengambil semua langkah yang mungkin untuk menghapuskan praktek yang secara internasional dianggap benar-benar tak tertahankan. Praktek khitan di negara tersebut erat kaitannya dengan tradisi sosial, dari 28 negara di Afrika, female circumsitition paling banyak terjadi di Somalia (Gele, 2013). Upaay penghapusan female circumsitition ini dengan Komitmen Internasional diwujudkan melalui PBB (Perserikatan Bangsa-Bangsa), pada awal Januari 2003 meluncurkan kampanye zero tolerance atas praktik khitan perempuan (Santi, 2006).

Kajian tentang sunat perempuan juga banyak dilakukan di Indonesia salah satunya penelitian di kota Semarang Indonesia tahun 2009, menunjukkan tiga responden yang mengalami FGM (female genital mutilation) atau khitan dan 1 orang dukun bayi yang sering melakukan sunat pada anak perempuan dapat diketahui bahwa praktik FGM pada perempuan di kota Semarang pada khususnya dipengaruhi oleh 2 alasan utama yaitu alasan agama terutama agama Islam dari ajaran mazhab Syafi'i yang mengharuskan seorang perempuan dikhitan. Alasan kedua yaitu alasan budaya karena penelitian di wilayah kota Semarang maka budaya yang dipakai adalah budaya Jawa. Menurut budaya Jawa seorang anak baik laki-laki maupun perempuan dianggap sudah menjadi umat Islam apabila sudah disunat. Sedangkan perspektif perempuan pada FGM menurut para perempuan yang menjadi responden mengatakan bahwa khitan yang mereka lakukan bukanlah hal yang membahayakan dan tentu saja mereka akan meneruskan tradisi khitan kepada anak-anak mereka kelak (Saputra, 2009). Menurut Putranti yang melakukan penelitian tentang sunat perempuan di Yogyakarta dan Madura menyebutkan bahwa sunat perenpuan lebih cenderung pada alasan tradisi bukan agama karena budaya itu muncul bahkan sebelum agama Islam masuk ke Indonesia (Putranti, 2003).

Jadi tidak bisa dipungkiri bahwa,meski ditentang berbagai negara karena dinilai melanggar hak-hak reproduksi kaum perempuan, praktik sunat perempuan masih banyak dilakukan di Indonesia bahkan di daerah kota modern sekalipun. Mengantisipasi praktik khitan perempuan yang tidak aman maka oleh pemerintah Indonesia, sunat perempuan tidak dilarang tapi hanya boleh dilakukan di bagian tertentu.Atas dasar itu pula maka dikeluarkan Permenkes No 1636/Menkes/Per/XI/2010 tentang sunat perempuan yang tentunya memiliki dampak negatif dan positif terhadap status kesehatan reproduksi wanita Indonesia. 
Permenkes yang dikeluarkan tahun 2010 ini banyak menimbulkan pro dan kontra. Dalam banyak kasus, perempuan disunat saat masih kecil ketika belum bisa menentukan pilihan sendiri. Melalui Dirjen Bina Kesehatan masyarakat, Kementerian Kesehatan (Kemenkes) pernah melarang medikalisasi sunat perempuan. Sementara dalam Permenkes tersebut, sunat perempuan justru diatur sedemikian detail mulai dari prosedur dan teknik penyayatan hingga bagian yang boleh disayat. Sungguh ini merupakan keadaan ironi yang sering dihadapi oleh bangsa Indonesia. Satu sisi karena fakta yang ada bahwa praktik sirkumsisi ini masih banyak dilakukan di beberapa daerah oleh dukun anak atau tenaga nonmedis tanpa memperhatikan kesterilan alat yang digunakan bisa memicu infeksi sehingga dibuatkan peraturan untuk melindungi dari tindakan yang tidak aman. Namun di sisi lain ketika dunia internasional menyuarakan untuk penghapusan khitan perempuan, Indonesia melegalkan tindakan tersebut melalui Permenkes tersebut dan dialkukan oleh tenaga medis. Ironinya lagi dalam kurikulum dokter, perawat, maupuan bidan di Indonesia tidak ada kompetensi untuk khitan perempuan tersebut. Perarutan ini menimbulkan berbagai reaksi karena dengan adanya Permenkes sunat perempuan justru melegalkan sunat perempuan dan dikhawatirkan makin melestarikan praktik-praktik semacam itu dan di sisi lain sirkumsisi ini sebenarnya tidak ada manfaatnya bagi perempuan bahkan lebih banyak kearah merugikan dan mengintimidasi perempuan. Sisi positifnya permenkes sebenarnya bertujuan untuk melindungi perempuan dari sunat ilegal yang membahayakan jiwa dan sistem reproduksinya. Atas dasar uraian tersebut dan pemaparan masalah sunat perempuan yang ada maka penulis mencoba untuk mengangkat masalah sunat perempuan ini dan membahas pro kontra yang muncul dari sunat perempuan di Indonesia.

Metode yang digunakan dalam kajian ini adalah systematic review atau analisis wacana dengan cara mengkaji dari beberapa sumber, bahan referensi, kajian dan aturan yang telah ada untuk kemudian diekstrak untuk membuat suatu kesimpulan yang bersifat induktif.

\section{PEMBAHASAN}

\subsection{Kategori Sunat atau Khitan Perempuan}

Khitan laki-laki yang telah membudaya di berbagai belahan dunia, dilaksanakan dalam bentuk yang hampir sama di semua tempat, yaitu pemotongan kulup penis (kulit kepala zakar) laki-laki. Adapun khitan bagi perempuan dilakukan secara berbeda untuk masing-masing tempat. Ada yang hanya sebatas membasuh ujung klitoris, ada yang membuang sebagian klitoris, dan ada yang membuang seluruh klitoris, bahkan ada pula yang sampai memotong labia minora (bibir kecil vagina) kemudian menjahit labia majora (bibir luar) setelah terlebih dahulu membuang seluruh klitoris. Tiga bentuk yang terakhir, lebih sering diistilahkan dengan Female Genital Mutilation (FGM). Female Genital Mutilation, menurut Nahid Tolibia dalam bukunya Female Genital Mutilation: a Call for Global Action, dapat dikategorikan menjadi dua (Nahid Toubia, 1993: 55 dalam Waliko,2009)

1. Clitoridectomy, yaitu menghilangkan sebagian atau lebih alat kelamin luar. Yang termasuk dalam kelompok ini adalah:

a. menghilangkan sebagian atau seluruh klitoris, dan

b. menghilangkan klitoris dan sebagian bibir kecil vagina (labia minora); 
2. Infibulation, yaitu menghilangkan seluruh klitoris serta sebagian atau seluruh labia minora, kemudian labia minora dijahit dan hampir menutupi seluruh vagina. Bagian yang terbuka hanya disisakan sedikit untuk pembuangan darah menstruasi, yang kadangkala hanya sekecil kepala batang korek api atau ujung kelingking. Jika perempuan tersebut menikah dan akan bersenggama (sexual intercouse), maka kulit tersebut dipotong atau dibuka kembali.

\subsection{Sunat Perempuan di Indonesia}

Satu-satunya informasi mengenai sunat perempuan di Indonesia yang cukup lengkap adalah studi Schrieke pada tahun 1921 yang mengindikasikan praktik sunat perempuan di sebagian besar Indonesia,dilakukan secara rahasia, pada usia sangat muda, yaitu dengan menghilangkan sebagian kecil ujung klitoris (Putranti, 2003) Berdasarkan Permenkes no 1636/Menkes/Per/XI/2010, sunat perempuan tidak dapat dilakukan pada perempuan yang sedang menderita infeksi genetalia eksterna atau infeksi umum lainnya. Sunat perempuan dilarang dilakukan dengan cara mengkauterisasi klitoris, memotong atau merusak klitoris baik sebagian dan seluruhnya, maupan memotong dan merusak labia minora, labia mayora, hymen atau selaput dara, seta bagian vagina yang lain. Dalam ketentuan itu juga diatur bahwa sunat perempuan hanya boleh dilakukan oleh tenaga medis yang terlatih seperti dokter, bidan dan perawat. Permenkes ini menyebutkan bahwa sunat perempuan adalah tindakan menggores kulit yang menutupi bagian depan klitoris,tanpa melukai klitoris.

Fakta yang ada dalam prakteknya sirkumsisi masih banyak dilakukan oleh non medis seperti dukun bayi (Saputro, 2009). Penelitian di Indonesia pada beberapa daerah tentang sunat perempuan hasilnya di Padang hampir 88,5\% dan Padang Pariaman 67,5\% dilakukan oleh tenaga medis, sedangkan sisanya non tenaga medis. Sementara itu di Makassar dan Bone hampir 100\% sunat perempuan dilakukan oleh non tenaga kesehatan atau dukun beranak (Oktarina, 2011). Survei yang dilakukan di Yogyakarta dan Madura mengindikasikan 'agama' dan 'tradisi' sebagai dua alasan dominan yang mendorong berlangsungnya praktik sunat perempuan. Di Madura misalnya, sekitar 79,3 persen dari total responden menyatakan agama sebagai alas an mereka mengalami sunat. Di Yogyakarta, alasan mengalami sunat perempuan lebih bervariasi: 31 persen dari total responden mengatakan untuk alasan agama, 26,2 persen untuk alasan tradisi, dan 26,2 persen lainnya sekedar mengikuti kemauan orang tua. Yang terakhir ini mengindikasikan masih berlanjutnya upaya untuk melanggengkan praktik sunat perempuan dari generasi ke generasi baik untuk alasan agama maupun tradisi ( Putranti, 2003).

\subsection{Perlindungan Kesehatan Reproduksi Terhadap Sunat Perempuan}

Sunat perempuan dilakukan dengan berbagai alasan, tetapi pada intinya bukan merupakan suatu hal yang wajib dilakukan. Untuk dapat dilakukan sunat perempuan, harus atas dasar permintaan dan persetujuan dari perempuan yang disunat, orang tua, dan/atau walinya (Pasal 3 ayat [1] Permenkes 1636/2010). Apabila sunat dilakukan pada bayi perempuan, maka harus dilakukan dengan permintaan dan persetujuan orang tua atau walinya. Sebelum sunat perempuan dilakukan, harus diinformasikan kemungkinan terjadi pendarahan, infeksi, dan rasa nyeri (Pasal 3 ayat (2) Permenkes 1636/2010). Persetujuan yang diberikan setelah mendapatkan informasi medis biasa disebut dengan informed consent. 
Praktik sunat perempuan ini menimbulkan perdebatan akan risiko yang mungkin ditimbulkannya. Namun, mengutip penjelasan dari salah satu artikel di laman resmi Kementerian Kesehatan berjudul, Permenkes Nomor 1636 Tahun 2010 tentang Sunat Perempuan: Menjamin Keamanan dan Perlindungan Sistem Reproduksi Perempuan, dijelaskan bahwa sebenarnya tidak perlu khawatir dengan praktik sunat perempuan, karena Permenkes 1636/2010 dibuat untuk menjamin keamanan dan perlindungan sistem reproduksi perempuan sesuai dengan prosedurnya.

Jika sunat perempuan dilarang dilakukan oleh tenaga kesehatan, padahal pada kenyataannya di masyarakat praktik tersebut masih berlangsung, dikhawatirkan masyarakat yang ingin menyunat bayi perempuannya justru akan pergi ke dukun dan hal tersebut justru akan menimbulkan berbagai komplikasi. Jika tenaga kesehatan mendapat permintaan dari pasien atau orang tua bayi perempuan untuk melakukan tindakan sunat, maka prosedur sunat perempuan harus dilakukan sesuai Permenkes 1636/2010 dan hal tersebut akan menjamin keamanan dan perlindungan sistem reproduksi perempuan. Jadi, sunat perempuan yang diatur dalam Permenkes 1636/2010 ditujukan untuk memberikan perlindungan pada perempuan dengan pelaksanaan sunat perempuan yang dilakukan sesuai dengan ketentuan agama, standar pelayanan, dan standar profesi untuk menjamin keamanan dan keselamatan perempuan yang disunat. Tidak ada kaitannya dengan asas gender dan non-diskriminatif ( Hadi, 2012, Hotman, 2010).

\subsection{Dampak Sunat Perempuan}

Agama hanya mewajibkan sunat untuk laki-laki, sementara dari aspek medis sunat perempuan justru berisiko memicu infeksi pada organ reproduksi. Sunat bagi perempuan tidak ada manfaatnya sama sekali. Untuk itu, Fakultas Kedokteran tidak ada yang mengajarkan khitan untuk wanita. Kecil atau tidaknya tindakan yang dilakukan karena berada dalam area sensitif wanita. Hal itu dinilai sangat berbahaya. Mulai dari pembedahan sampai anastesi, yang paling parah dari khitan bisa menimbulkan kematian.Dampak jangka pendek sunat pada perempuan (Oktarina, 2011) :

1) Perdarahan yang mengakibatkan shock atau kematian,

2) Infeksi pada seluruh organ panggul yang mengarah pada sepsis,

3) Tetanus yang menyebabkan kematian,

4) Gangrene yang dapat menyebabkan kematian,

5) Sakit kepala yang luar biasa mengakibatkan shock,

6) Retensi urin karena pembengkakan dan sumbatan pada uretra.

Dampak jangka panjang adalah:

1) Rasa sakit berkepanjangan pada saat berhubungan seks,

2) Penis tidak dapat masuk dalam vagina sehingga memerlukan tindakan operasi,

3) Disfungsi seksual (tidak dapat mencapai orgasme pada saat berhubungan seks),

4) Disfungsi haid yang mengakibatkan hematocolpos (akumulasi darah haid dalam vagina), hematometra (akumulasi darah haid dalam rahim), dan hematosalpinx (akumulasi darah haid dalam saluran tuba),

5) Infeksi saluran kemih kronis,

6) Inkontinensi urine (tidak dapat menahan kencing),

7) Bisa terjadi abses, kista dermoid, dan keloid (jaringan parut mengeras) 


\subsection{Pro dan Kontra Khitan atau Sunat Perempuan di Indonesia}

Praktik sunat perempuan yang tersebar di beberapa wilayah ternyata berdampak negatif pada perempuan sehingga membuat PBB, pada awal Januari 2003 meluncurkan kampanye zero tolerance atas praktik khitan perempuan. Data yang dimiliki PBB menunjukkan bahwa lebih dari 150 juta perempuan, terutama remaja dan anak-anak, mengalami penderitaan akibat praktik melukai atau memotong alat kelamin perempuan ini. Dampak buruk khitan perempuan bisa berupa pendarahan, infeksi rasa sakit yang hebat, ketidaksuburan, anemia, tetanus hingga masalah psikologis dan persoalan kejiwaan yang membahayakan kehidupan perempuan dan anak perempuan. Pendeknya, khitan perempuan dinilai dapat merusak hak reproduksi wanita ( Santi, 2006)

Khitan perempuan yang dilakukan di Yogyakarta dan Madura menunjukkan keadaan yang mendukung terhadap sunat perempuan. Seiring dengan proses medikalisasi, sunat perempuan di Yogyakarta dan Madura dewasa ini telah mengalami pergeseran dalam hal prosedur dari 'pemotongan yang sesungguhnya' oleh dukun ke arah 'sekedar pembersihan' oleh bidan. Pergeseran ini didukung oleh data survei yang mengatakan bahwa dari berbagai prosedur sunat yang dilakukan, sangat jarang diantaranya yang menimbulkan dampak komplikasi serius bagi perempuan. Kenyataan ini juga menyebabkan sunat perempuan di daerah penelitian tidak pernah diperhitungkan sebagai sebuah isu kebijakan. Jika demikian, lantas apa relevansinya bagi persoalan kesehatan reproduksi perempuan? Hasil penelitian ini justru menyarankan agar pengalaman Indonesia dapat menjadi model bagi negara-negara lain yang masih melakukan praktik sunat perempuan yang berbahaya. Dalam hal ini, terciptanya iklim budaya yang lebih terbuka sebagaimana tercermin di Yogyakarta, serta prosedur pembersihan alat kelamin yang diperkenalkan oleh bidan di kedua daerah penelitian dapat menjadi pelajaran yang berharga bagi berbagai upaya pengurangan praktik sunat perempuan yang dapat membahayakan kesehatan reproduksi (Putranti, 2003)

Data survei menunjukkan bahwa 35,9 persen dari pelaksanaan sunat perempuan di Madura dilakukan dengan cara memotong ujung klitoris; dan 27 persen dengan cara menggores klitoris atau labia tanpa ataupun disertai pendarahan. Kemudian pemotongan atau penggoresan dilakukan menggunakan peralatan seperti silet, pemes, gunting, atau welat (Jawa: bambu tajam). Di Yogyakarta, prosedur pemotongan atau penggoresan oleh dukun juga dilakukan meski tidak begitu tinggi prevalensinya: 8,8 persen dengan cara menggores klitoris atau labia tanpa ataupun disertai pendarahan; dan 11,2 persen dengan cara memotong ujung klitoris. Namun prosedur semacam ini sudah semakin sulit ditemukan di kalangan generasi mudanya.

( Putrianiti,2003).

Keadaan yang terjadi kini diIndonesia bahwa Kementerian Kesehatan pada 2013 telah mencabut Peraturan Menteri Kesehatan tahun 2010 yang mengatur tentang praktik sunat perempuan.Wakil Menteri Kesehatan Ali Qufron Mukti menyatakan bahwa pencabutan itu dikarenakan banyaknya pihak yang berpikir bahwa sunat perempuan yang dilakukan di Indonesia sama dengan di Afrika dan di Indonesia, lanjutnya, sunat perempuan dilakukan dengan cara mengores kulit yang menutupi bagian depan klitoris dengan 
menggunakan jarum teril tanpa melukainya. Pencabutan peraturan tersebut tidak banyak diketahui khalayak (Wardah, 2014).

Tujuan dilakukannya sunat perempuan itu diasumsikan sebagai salah satunya tindakan untuk mengekang seksualitas perempuan. Secara medis sebenarnya tidak ada keuntungan secara medis ketika dilakukan sunat perempuan berbeda ketika itu dilakukan kepada laki-laki. Sunat perempuan tidak ada dalam kurikulum bidan atau dokter. Mereka selama ini melakukannya tidak melalui pendidikan. Pemerintah harus melakukan upaya peningkatan kesadaran, pendidikan dan kampanye secara luas kepada kelompok-kelompok agama dan budaya, pemimpin politik, dan masyarakat pada umumnya untuk mengubah persepsi budaya dan keyakinan tentang sunat perempuan. Harapannya, masyarakat Indonesia sadar betul bahwa praktik itu adalah praktik yang merugikan perempuan. Biarkan perempuan menikmati tubuhnya, biarkan perempuan punya hak atas tubuhnya. Sebelum peraturan menteri kesehatan tahun 2010 yang membolehkan sunat perempuan dikeluarkan, pemerintah pada 2006 sebenarnya telah membuat kebijakan untuk melarang praktik sunat perempuan. Namun sayangnya, Majelis Ulama Indonesia (MUI) menentang kebijakan tahun 2006 dan mendesak pihak Kementrian Kesehatan untuk tidak melarang praktik sunat perempuan.

Selain penelitian tentang sunat perempuan di Yogyakarta, Semarang dan Madura, penelitian juga dilakukan di kota Banjarmasin.pelaksanaan sunat perempuan pada masyarakat Banjar di Kota Banjarmasin dilakukan dengan cara memotong sedikit klitoris anak perempuan pada usia antara empat puluh hari sampai dengan dua belas bulan dan yang menyunat adalah bidan atau dukun bayi. Alat yang digunakan untuk menyunat dan cara penyunatan berbeda antara bidan dan dukun bayi. Dalam pelaksanaan sunat perempuan tidak ada ritual khusus.

Masyarakat Banjar menganggap bahwa sunat perempuan merupakan kebiasaan yang tidak bisa ditinggalkan karena merupakan salah satu dari perintah agama. Selain itu juga karena alasan tradisi yang tidak bisa mereka tinggalkan. Perasaan lega dan tidak punya beban mereka rasakan jika sudah menyunat anak perempuannya. Ada sebagian masyarakat yang terperanjat dan kaget ketika sunat perempuan dipertanyakan. Kekagetan ini muncul karena mereka menganggap sunat perempuan sebagai sutau kebiasaan yang biasa dilakukan sehingga tidak perlu dipertanyakan dan tabu jika hal tersebut diperbincangkan.Makna sunat perempuan bagi masyarakat Banjar yang melakukan sunat perempuan di antaranya menjadi simbol untuk selalu menjaga kesucian diri dan keturunan. Bagi sebagian informan dalam memaknai sunat perempuan sebagai suatu cara untuk melanjutkan keturunan, karena mereka beranggapan bahwa sunat perempuan akan melancarkan proses persalinan kelak kalau si anak sudah berkeluarga, sehingga mereka takut kalau tidak disunat tidak akan mendapatkan keturunan (Nurdiyana, 2010).

\section{PENUTUP}

\subsection{Kesimpulan}

Indikator masalah kesehatan perempuan (kesehatan reproduksi) masih menimpa perempuan Indonesia misalnya sunat perempuan, tingkat kematian ibu yang masih tinggi, tingginya aborsi, tingkat infeksi menular seksual termasuk HIV/AIDS juga relative tinggi, angka peserta $\mathrm{KB}$ aktif yang tidak meningkat, rendahnya partisipasi pria dalam keluarga 
berencana, serta kurangnya pengetahuan keluarga, tentang kesehatan reproduksi. Permasalahan kesehatan yang menimpa perempuan lebih banyak terkait dengan fungsi reproduksinya.

Sunat perempuan di Indonesia pun menjadi permasalahan yang sering dianggap wajar karena alasan pelestarian budaya dan tradisi. Sunat perempuan sendiri di Indonesia diatur dalam Permenkes nomor 1636/Menkes/Per/XI/2010 yang awalnya bertujuan untuk menjamin keamanan dan perlindungan sistem reproduksi perempuan karena faktanya di Indonesia masih banyak praktek sunat perempuan dilakukan oleh dukun bayi dan secara rahasia. Namun hal ini justru mengindikasikan untuk melegalkan tindakan sirkumsisi pada perempuan yang jelas-jelas belum ada evaluasi yang menunjukkan bahwa sirkumsisi itu bermnafaat bagi kesehatan reproduksi perempuan. Berbagai reaksi muncul di masyarakat sehingga Permenkes tentang sunat perempuan ini dicabut pada tahun 2013. Jadi sunat perempuan itu merupakan sebuah tradisi yang bergeser kearah tindakan medikalisasi yang bermanfaat bagi kaum laki-laki namun merugikan bagi kaum perenpuan. Secara medis khitan perempuan belum menunjukkan tingkat validitas kebaikan yang dapat dipertanggungjawabkan. Tradisi khitan perempuan berkemungkinan besar didasarkan atas mitos-mitos yang berkembang di masyarakat, yang menganggap perempuan sebagai makhluk subordinasi dari laki-laki.

\section{DAFTAR PUSTAKA}

Hotman Siahaan,H. 2010. Perlindungan hukum reproduksi perempuan di Indonesia. Majalah Fakultas Hukum Universitas Palembang. No. 16 Tahun VI Januari 2010

Hadi,I.2012.SunatPerempuan.http://www.hukumonline.com/klinik/detail/lt5004324178331/sun at-perempuan.Diakses tanggal: 21 maret 2014.

Nurdiyana,T. 2010. Sunat Perempuan Pada Masyarakat Banjar Di Kota Banjarmasin. Jurnal Komunitas. Vol.2 Hal:116-124 http://journal.unnes.ac.id/nju/index.php/komunitas. Diakses tanggal 22 Maret 2014

Oktarina. 2011. Permenkes Sunat Kaum Perempuan: Pro Dan Kontra Antara Tradisi Dan Perlindungan Kepentingan Perempuan. Jurnal Manajemen Pelayanan Kesehatan. Vol.14 No. 04 Hal:177-180

Permenkes nomor 1636/Menkes/Per/XI/2010 tentang Sunat Perempuan

Santi,S. 2006. Khitan Perempuan Legitimasi Agama dan Budaya Atas Kekerasan dan pengendalian Tubuh Perempuan. Forum Ilmiah Indonesia. Vol.3.No.1

Saputro, S.E. 2009. Female Genital Mutilation (Fgm) Ditinjau Dari Pengalaman Perempuan Yang Mengalami Fgm. Thesis, Unika Soegijapranata 
Putranti,B.D. 2003. Sunat Perempuan: Cermin Bangunan Sosial Seksualitas Masyarakat Yogyakarta dan Madura. Paper. UGM

Waliko. 2009. Telaah atas konsep khitan bagi wanita. Jurnal studi gener dan anak STAIN Purwokerto. Vol.4 no.2 Hal: 222-233

Wardah,F.2014. Peraturan Menteri Kesehatan RI Soal Sunat Perempuan Telah Dicabut. http://www.voaindonesia.com/content/peraturan-menteri-kesehatan-ri-soal-sunatperempuan-telah-dicabut/1839905.html. Diakses tanggal : Jumat 21 Maret 2014. 